\author{
Agnieszka Fihel \\ Ośrodek Badań nad Migracjami Uniwersytetu Warszawskiego \\ a.fihel@uw.edu.pl
}

Magdalena Muszyńska

Instytut Statystyki i Demografii

Szkoła Główna Handlowa w Warszawie

mmuszyns@sgh.waw.pl

Wiktoria Wróblewska

Instytut Statystyki i Demografii

Szkoła Główna Handlowa w Warszawie

wwrobl@sgh.waw.pl

\title{
UMIERALNOŚĆ Z PRZYCZYN NIEZNANYCH I NIEDOKŁADNIE OKREŚLONYCH ORAZ JEJ TRWAŁE ZRÓŻNICOWANIE TERYTORIALNE W POLSCE ${ }^{1}$
}

\begin{abstract}
WSTĘP
Dzięki rzetelnym i dokładnym danym epidemiologicznym możliwe jest prawidłowe określenie celów polityki zdrowotnej państwa oraz ocena jej skuteczności. Wśród danych odnoszących się do zdrowia i zachorowalności szczególne miejsce zajmują informacje o zgonach i ich przyczynach. Dane te zbierane są w trybie ciągłym, systematycznym i obowiązkowym. Przyczynia się to aktualności i kompletności tych danych, choć sama organizacja systemu ich pozyskiwania nie przesądza o ich wysokiej jakości. Jednym z czynników utrudniającym pełną ocenę sytuacji zdrowotnej ludności na podstawie statystyki zgonów jest rejestracja zgonów z przyczyn nieznanych i niedokładnie określonych (NN).
\end{abstract}

1 Tekst powstał w ramach grantu finansowanego przez Narodowe Centrum Nauki „Terytorialne zróżnicowanie umieralności w Polsce" nr 2011/01/B/HS4/04797. Autorki pragną podziękować anonimowym Recenzentom za wartościowe uwagi, które przyczyniły się do powstania ostatecznej wersji tekstu. 
W Polsce orzekanie zgonów z przyczyn nieznanych i niedokładnie określonych jest zjawiskiem stosunkowo częstym. Przyczyny te oznaczone są w 10-tej rewizji (nowelizacji) Międzynarodowej Statystycznej Klasyfikacji Chorób i Problemów Zdrowotnych (International Statistical Classification of Diseases and Related Health Problems, ICD) za pomocą kodów R00-R99. W 2010 roku przyczyny NN dotyczyły $6,5 \%$ wszystkich osób zmarłych, stanowiąc tym samym trzecią, po chorobach układu krążenia i nowotworach, najważniejszą grupę przyczyn zgonów (Wojtyniak i inni 2012b). W Unii Europejskiej tylko kilka krajów wyprzedza Polskę pod względem skali orzecznictwa zgonów z przyczyn nieznanych i niedokładnie określonych: Grecja i Portugalia (po 9,5\% zgonów w 2010 roku), Dania (8,5\% w 2009 roku) i Francja (8,3\% w 2010 roku). Warto zauważyć, że od czasu przyjęcia 10-tej rewizji Międzynarodowej Statystycznej Klasyfikacji Chorób w 1997 roku i zakończenia strajku lekarzy w 1999 roku odsetek zgonów z przyczyn nieznanych i niedokładnie określonych w Polsce systematycznie spada ${ }^{2}$, jednak dystans dzielący nasz kraj od pozostałych członków Unii Europejskiej utrzymuje się na prawie stałym poziomie (Ryc. 1). W Polsce zgony z przyczyn NN orzeka się stosunkowo często w przypadku 30-, 40- i 50-latków i jest to kolejna zasadnicza różnica w stosunku do praktyki stosowanej w innych krajach europejskich, w których zgony te rozpoznaje się przede wszystkim w pierwszych latach życia oraz - w dalszej kolejności - w okolicach 30-tego roku życia.

Wysoki odsetek zgonów z przyczyn nieznanych i niedokładnie określonych spowodował, iż w opracowaniu wydanym pod auspicjami Światowej Organizacji Zdrowia Polska została zaliczona do krajów o niskiej jakości danych odnoszących się do umieralności ${ }^{3}$ (Mathers $i$ in. 2005). W literaturze przedmiotu przywoływany jest jednak argument, iż częsta rejestracja przyczyn nieznanych i niedokładnie określonych może świadczyć o ostrożności lekarzy orzekających o zgonie i jego okolicznościach, dzięki czemu zgony, co do których przyczyn istnieją wątpliwości nie są błędnie przypisane innym przyczynom. Z kolei we Francji orzeka się przyczyny nieznane i niedokładnie wobec wszystkich zgonów, wobec których toczą się czynności dochodzeniowo-śledcze (Bijak 2003). Dlatego niski odsetek zgonów z przyczyn NN nie świadczy automatycznie o dobrej jakości danych statystycznych, czego

2 Akcja protestacyjna polegała między innymi na odstąpieniu od obowiązku wypełnienia karty zgonu w zakresie przyczyn zgonu i chorób towarzyszących, i dlatego informacji tych brakuje w odniesieniu do 20\% zgonów mających miejsce w latach 1997-1998. W sprawozdawczości Głównego Urzędu Statystycznego dane te ujęte zostały w odrębnej kategorii, jako zgony bez podania przyczyny, a nie jako zgony z powodu przyczyn nieznanych. Strajk został ostatecznie zakończony w 2002 roku, jednak już po 1999 roku jego skala była marginalna.

3 Oprócz rozdziału „objawy, cechy chorobowe oraz nieprawidłowe wyniki badań klinicznych...” autorzy zaliczyli do przyczyn niedokładnie określonych zdarzenia o nieokreślonym zamiarze (kody Y10-Y34 i Y87.2 w 10-tej rewizji Międzynarodowej Statystycznej Klasyfikacji Chorób i Problemów Zdrowotnych), choroby układu krążenia bez konkretnej diagnozy (I46, I47.2, I49.0, I50, I51.4-I51.6, I51.9, I70.9) i wybrane nowotwory złośliwe o niedokładnie określonym umiejscowieniu (C76, C80, C97). 
Umieralność z przyczyn nieznanych i niedokładnie określonych oraz jej trwałe...

często cytowanym w literaturze przedmiotu przykładem pozostaje Rosja ${ }^{4}$, w której przyczyny te były orzekane w latach 1970-1989 niezwykle rzadko, bo w odniesieniu do mniej niż 1\% wszystkich zgonów (Meslé 2002).

Ryc. 1. Odsetek zgonów z przyczyn nieznanych i niedokładnie określonych* wśród wszystkich zgonów w Polsce i Unii Europejskiej**, 1991-2010***

Fig. 1. Deaths due to unknown and ill-defined causes* as percentage of all deaths in Poland and European Union**, 1991-2010***

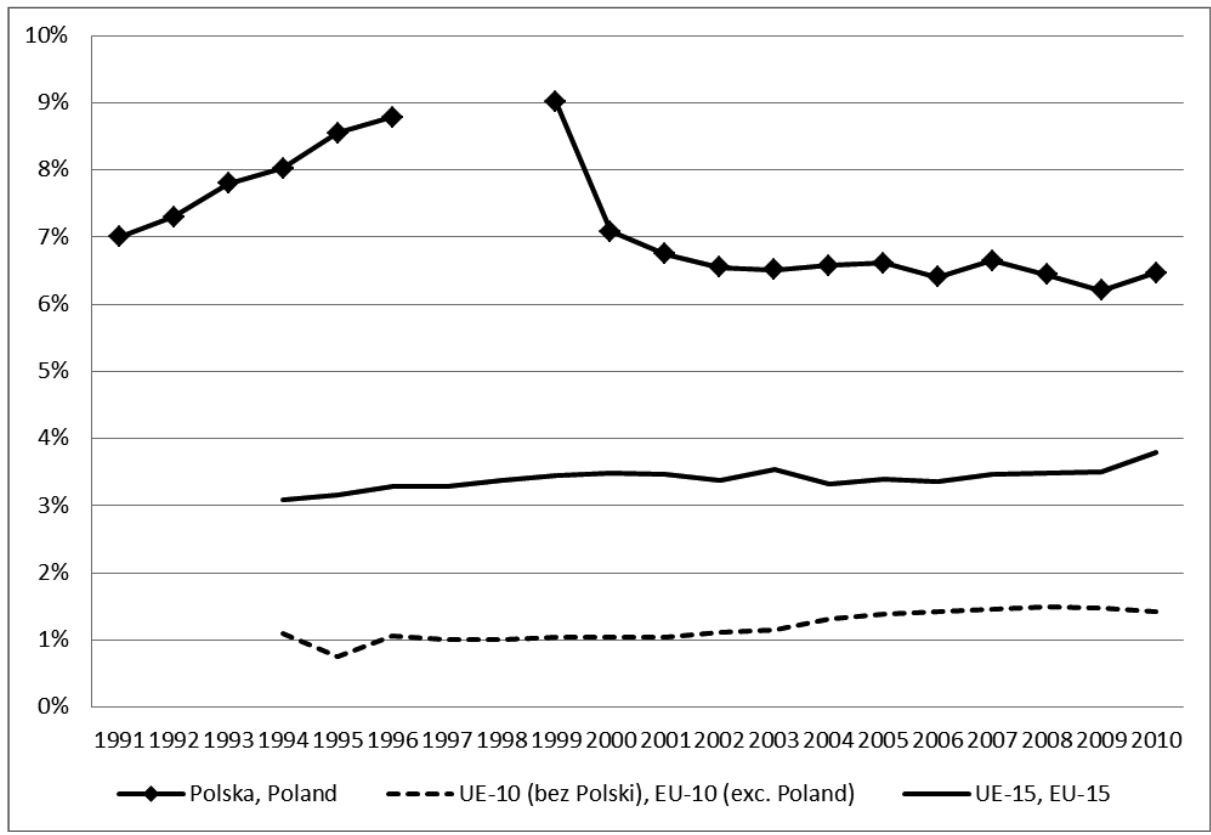

* Kody R00-R99 według 10-tej rewizji lub 780-799 według 9-tej rewizji ICD. ** UE-10 (bez Polski): Cypr, Republika Czeska, Estonia, Litwa, Łotwa, Malta, Słowacja, Słowenia, Węgry; UE-15: Austria, Belgia, Dania, Finlandia, Francja, Grecja, Hiszpania, Holandia, Irlandia, Luksemburg, Niemcy, Portugalia, Szwecja, Wielka Brytania, Włochy. *** Braki danych dla lat 1997-1998 spowodowane strajkiem polskich lekarzy.

Źródło: opracowanie własne na podstawie danych Eurostatu (2013).

* Codes R00-R99 according to the 10th ICD revision and codes 780-799 according to the 9th revision. ** EU-10 (excluding Poland): Cyprus, Czech Republic, Estonia, Hungary, Latvia, Lithuania, Malta, Slovakia, Slovenia; EU-15: Austria, Belgium, Denmark, Finland, France, Germany, Greece, Ireland, Italy, Luxembourg, the Netherlands, Portugal, Spain, Sweden, the United Kingdom. *** No data available for Poland for 1997-1998 due to protest of medical doctors. Source: own elaboration based on Eurostat (2013).

W ogólności, zjawisko częstego orzekania przyczyn nieznanych i niedokładnie określonych jest niekorzystne dla statystyki zdrowia publicznego przynajmniej

4 Rosyjska Federacyjna Socjalistyczna Republika Radziecka. 
z dwóch powodów: po pierwsze, utrudnia ono ocenę sytuacji epidemiologicznej i zdrowotnej populacji. Ma to tym większe znaczenie, gdy istnieją przesłanki świadczące o tym, że przyczyny NN są zdecydowanie częściej orzekane w przypadku wybranych grup ludności lub zdecydowanie częściej „,zastępują” wybrane, dokładnie określone przyczyny. W przywołanej już Rosji udział przyczyn nieznanych i niedokładnie określonych wzrósł w latach 90 . XX wieku z 0,8 do $4 \%$ wszystkich zgonów mężczyzn i z 0,8 do 5,5\% zgonów kobiet. Gavrilova i in. (2008) pokazali, że za wzrost ten odpowiedzialna była przede wszystkim nieprawidłowa klasyfikacja zewnętrznych przyczyn zgonu o nieokreślonym zamiarze ${ }^{5}$, w stosunku do których nie można było sprecyzować, czy zgon nastąpił w wyniku wypadku, zamierzonego samouszkodzenia, czy napaści. Po drugie, zjawisko częstego orzekania przyczyn nieznanych i niedokładnie określonych bardzo utrudnia prowadzenie międzynarodowych porównań trendów z dziedziny umieralności według przyczyn (Bijak 2003; por. też dla Czech, Francji i Polski: Pechholdová i Fihel 2013). W demograficznych badaniach poświęconych umieralności stosuje się najczęściej praktykę polegającą na proporcjonalnym rozszacowaniu zgonów z przyczyn nieznanych i niedokładnie określonych pomiędzy przyczyny określone (Meslé 2002). Tak przygotowane statystyki są używane do porównań międzynarodowych. Praktyka ta jest jednak nieprawidłowa, jeśli w danym kraju przyczyny NN orzeka się częściej zamiast jednej lub kilku wybranych przyczyn dokładnie określonych. Dla Polski Bijak (2003) pokazał, iż w województwach o niskim orzecznictwie zgonów z powodu cukrzycy orzecznictwo przyczyn nieznanych i niedokładnie określonych jest istotnie wyższe, i vice versa, co może świadczyć o tym, że w praktyce kodyfikacyjnej przyczyny NN mogą być stosunkowo często orzekane zamiast cukrzycy, a występowanie tej ostatniej w Polsce (jako przyczyny zgonu) może być niedoszacowane w danych statystyki publicznej.

Powyższy wynik pokazuje, że w przypadku Polski ostrożność lekarzy nie jest główną przyczyną częstego rejestrowania przyczyn nieznanych i niedokładnie określonych i że występują lokalne różnice w orzekaniu przyczyn zgonu, w tym przyczyn NN. Na szczególną uwagę zasługują dane zawarte w Atlasie umieralności ludności Polski (Wojtyniak i in. 2012b), które świadczą o prawidłowości sąsiadowania ze sobą obszarów o zbliżonych wskaźnikach umieralności dla większości analizowanych przyczyn ${ }^{6}$. Dotyczy to także przyczyn nieznanych i niedokładnie określonych ${ }^{7}$, których wysoki poziom rejestracji obserwowany jest w sąsiadujących ze sobą powiatach województwa dolnośląskiego, lubelskiego, lubuskiego, łódzkiego, a stosunkowo

5 Chodzi o kategorie Y10-Y34 w 10-tej rewizji Międzynarodowej Statystycznej Klasyfikacji Chorób i Problemów Zdrowotnych.

6 Pokazują to również inne analizy, na przykład w odniesieniu do schorzeń układu sercowo-naczyniowego (Kupść i in. 2008), nowotworów (m.in. Zatoński i Tyczyński 1999) oraz innych chorób (Bijak 2003).

7 W cytowanej pracy przyczyny nieznane i niedokładnie określone obejmowały kategorie $R 95-R 99$, które stanowią ponad połowę zgonów zarejestrowanych za pomocą kodu $R$. 
Umieralność z przyczyn nieznanych i niedokładnie określonych oraz jej trwałe...

niski poziom - w sąsiadujących ze sobą powiatach województwa małopolskiego, mazowieckiego, pomorskiego, warmińsko-mazurskiego. Takie terytorialne „skupianie się" regionów charakteryzujących się wysokim - lub niskim - poziomem rejestracji umieralności z przyczyn nieznanych i niedokładnie określonych świadczyć może o znaczeniu lokalnych praktyk kodyfikacyjnych dla orzekania o przyczynach zgonu.

Celem niniejszego artykułu jest analiza terytorialnego zróżnicowania umieralności z przyczyn zgonów uznawanych jako nieznane i niedokładnie określone na poziomie powiatów, a w szczególności pokazanie, iż zróżnicowanie to ma charakter trwały (w czasie) oraz że istnieje tendencja do powstawania (i utrzymywania się w czasie) terytorialnych skupisk regionów o podobnej skali orzecznictwa przyczyn NN. Dokonano jej na poziomie powiatów na podstawie statystyki $I$ Morana, która służy weryfikacji hipotezy dotyczącej istnienia terytorialnych skupisk regionów o podobnym natężeniu danego zjawiska, w tym przypadku skali orzekania zgonów z przyczyn NN. Wzorce przestrzenne dla lat 2006-2010 zostały skontrastowane z sytuacją w latach 1991-1995 oraz pogłębioną analizą wzorca terytorialnego dotyczącego zmian pomiędzy tymi dwoma okresami. W dalszej części omawiane są możliwe przyczyny wysokiej i niejednorodnej terytorialnie rejestracji zgonów z przyczyn nieznanych i niedokładnie określonych oraz możliwe środki zaradcze.

\section{DANE WYKORZYSTANE W BADANIU ORAZ METODA ANALIZY}

Dane wykorzystane w niniejszej analizie pochodzą z Głównego Urzędu Statystycznego. Baza danych zawierała informację dotyczącą wszystkich zgonów według płci i wieku w powiatach (jednostki terytorialne LAU-1) oraz liczbę ludności według tych samych charakterystyk i stanu na 30 czerwca badanego roku. Sytuacja bieżąca opisana została na podstawie danych z lat 2006-2010 ze względu na to, iż były to ostatnie dostępne lata w momencie analizy. Wybór lat 1991-1995 do porównań rozwoju zjawiska w czasie podyktowany był tym, iż rok 1991 był rokiem o najwyższym poziomie umieralności, po którym rozpoczął się systematyczny spadek umieralności w Polsce. Przełomowe lata 1989-1990 cechował tymczasowy wzrost umieralności (Nolte i in. 2000) i dlatego rok 1991 stanowi punkt wyjściowy analiz przeprowadzonych w tym opracowaniu. Obliczenia wykonane zostały dla pięcioletnich grup wieku oraz pięciu lat kalendarzowych w celu eliminacji wahan przypadkowych, które byłyby spowodowane niską liczebnością podgrup ludności podlegających analizie.

Jako przyczyny nieznane i niedokładnie określone zdefiniowano kategorie przyczyn należące do 18-ego rozdziału 10-tej rewizji Międzynarodowej Statystycznej Klasyfikacji Chorób i Problemów Zdrowotnych: „objawy, cechy chorobowe oraz nieprawidłowe wyniki badań klinicznych i laboratoryjnych niesklasyfikowane gdzie indziej” (kody R00-R99), lub w przypadku 9-tej rewizji, należące do 16-ego roz- 
działu: „objawy, oznaki i stany niedokładnie określone” (kody 780-799). Chociaż w 10-tej rewizji wyróżniono ponad 90 przyczyn NN, to tylko kilka z nich jest używanych przez lekarzy orzekających w Polsce. Na przykład, spośród 24,5 tysiąca osób, które w 2010 roku zmarły z przyczyn nieznanych i niedokładnie określonych w Polsce, 99,6\% zaliczono do jednej z siedmiu kategorii: zatrzymanie oddechu (kod R09.2 według 10-tej rewizji ICD, 845 zgonów), starość (R54, 9104 zgony), kacheksja (czyli znaczne zmniejszenie się masy ciała) (R64, 154 zgony), śmierć natychmiastowa (R96.0, 8571 zgony), śmierć w ciągu pierwszych 24 godzin od pojawienia się objawów i nie dająca się wytłumaczyć inaczej (R96.1, 1062 zgony), śmierć nieoczekiwana $(R 98,540$ zgonów), lub inne, niedokładnie określone i nieznane przyczyny umieralności (R99, 4122 zgony).

Przyjęty w pracy powyższy sposób definiowania przyczyn nieznanych i niedokładnie określonych stanowi uproszczenie, ponieważ w rzeczywistości w każdym rozdziale klasyfikacji znajdują się przyczyny zgonu nie w pełni określone w zakresie miejsca rozwoju choroby, jej rodzaju, okoliczności urazu czy wypadku. Dotyczy to wszystkich kategorii, których skrótowy kod alfanumeryczny według 10-tej rewizji zakończony jest cyfrą „9”, na przykład: 170.9 - uogólniona i nieokreślona miażdżyca (przyczyna aż 28854 zgonów w 2010 roku w Polsce) czy J18.9 - nieokreślone zapalenie płuc (7 318 zgonów). Gdyby uwzględnić wszystkie kategorie zakończone cyfrą „9”, wówczas niedokładnie określone przyczyny dotyczyłyby co drugiego (!) zgonu rejestrowanego w Polsce (Fihel 2011).

W międzynarodowej literaturze poświęconej klasyfikacji przyczyn zgonów istnieje też pojęcie garbage codes, czyli kategorii „,́mieciowych”, „odpadowych”, „bezużytecznych”, odnoszących się do całego rozdziału $R$, urazów o nieokreślonym zamiarze (Y10-34, Y87.2), niesklasyfikowanych gdzie indziej nowotworów (C76, C80, C97) i chorób układu krążenia (I46, I47.2, I49.0, I50, I51.4-9, I70.9) (WHO 2013). Według najnowszej publikacji GUS (2014) odsetek zgonów z powyższych przyczyn wyniósł $27,5 \%$ w 2010 roku, a w 2012 roku - 28,3\%. Oprócz powyższych przyczyn, każdy rozdział klasyfikacji zawiera kategorie „niesklasyfikowane gdzie indziej”, o „niepewnym lub nieznanym charakterze”, „niedokładnie określonym umiejscowieniu”, ,nieokreślonym zamiarze” itp. O ile jednak te ostatnie są przyporządkowane konkretnym grupom przyczyn - chorobom zakaźnym i pasożytniczym, nowotworom, itd. - o tyle przyczyny zawarte w 18-tym rozdziale 10-tej rewizji (oznaczonym literą $R$ ), opierają się na bardzo nieprecyzyjnej diagnozie medycznej i nie służą lepszemu rozumieniu sytuacji epidemiologicznej, a nawet mogą ją zaburzać.

Terytorialne zróżnicowanie umieralności w Polsce opisane zostało na podstawie podstawowych statystyk dotyczących standaryzowanych odsetków zgonów ze względu na przyczyny nieznane i niedokładnie określone w powiatach. Standaryzacji dokonano w taki sposób, iż odsetki zgonów z przyczyn NN dla poszczególnych (5-letnich) grup wieku zostały przemnożone przez strukturę wieku ludności Polski z dnia 1 stycznia 2000 roku (Human Mortality Database 2013). Na tej podstawie 
Umieralność z przyczyn nieznanych i niedokładnie określonych oraz jej trwałe...

obliczono jeden (standaryzowany) odsetek zgonów z przyczyn NN dla każdego powiatu. W analizie celowo posłużono się standaryzowanym procentowym udziałem zgonów z przyczyn nieznanych i niedokładnie określonych wśród wszystkich zgonów, ponieważ miara ta stosunkowo dobrze obrazuje różnice regionalne w sposobie orzekania o umieralności. We wcześniejszych badaniach terytorialnego zróżnicowania umieralności analizowane były standaryzowane współczynniki zgonów z przyczyn nieznanych i niedokładnie określonych (np. Wojtyniak i in. 2012a, b). Standaryzowane współczynniki zgonów świadczyć mogą jednak zarówno o odmiennych praktykach w zakresie orzekania przyczyn zgonów, jak i o różnicach w ogólnym poziomie umieralności pomiędzy powiatami. Dopiero analiza zróżnicowania terytorialnego w oparciu o udział zgonów nieznanych i niedokładnie określonych pozwala na ocenę różnic w sposobie orzekania przyczyn wyjściowych, gdyż nie bierze się $\mathrm{w}$ niej pod uwagę różnic $\mathrm{w}$ umieralności per se. Ze względu na silną dodatnią korelację na poziomie powiatów odsetków zgonów z przyczyn NN dla kobiet i mężczyzn ( $r=0,72$, wartość nie została podana w Tablicach) oraz ze względu na podobne wartości analizowanych statystyk dla obu płci, analizy w prezentowanym badaniu prowadzone były dla obu płci łącznie.

$\mathrm{W}$ celu odpowiedzi na pytanie, czy istnieje wzorzec przestrzenny w orzekaniu przyczyn zgonów jako nieznane i niedokładnie określone, standaryzowane odsetki zgonów wykreślone zostały na mapach dla powiatów za pomocą programu kartograficznego MapInfo Professional (http://www.mapinfo.com/). Za pomocą pakietu statystycznego R (http://www.r-project.org) wyznaczone zostały statystyki I Morana dla standaryzowanego odsetka zgonów z przyczyny nieznanych i niedokładnie określonych w powiatach. Wartość statystyki I Morana informuje, jak duża jest zależność pomiędzy wartością statystyki w danym regionie oraz regionach bezpośrednio $\mathrm{z}$ nim sąsiadujących. Wyznacza się ją za pomocą wzoru:

$$
I=\frac{N}{\sum_{i=1}^{N} \sum_{j=1}^{N} w_{i j}} \times \frac{\sum_{i=1}^{N} \sum_{j=1}^{N} w_{i j}\left(y_{i}-\bar{y}\right)\left(y_{j}-\bar{y}\right)}{\sum_{i=1}^{N}\left(y_{i}-\bar{y}\right)}
$$

gdzie $y_{i}$ oraz $y_{j}$ stanowią wartości odsetków zgonów z przyczyn NN w $i$-tym oraz j-tym powiecie, $\bar{y}$ - średni odsetek dla całej Polski, $N$ oznacza liczbę powiatów. Standaryzowane wagi przestrzenne $w_{i j}$ obliczane są za pomocą wzoru:

$$
w_{i j}=\frac{c_{i j}}{\sum_{k} c_{i k}}
$$

gdzie $c_{i j}$ wynosi 1 , jeśli powiat $j$ sąsiaduje bezpośrednio z powiatem $i$, lub $0 \mathrm{w}$ przeciwnym przypadku, zaś suma $\Sigma_{k} c_{i k}$ oznacza liczbę wszystkich powiatów bezpośrednio sąsiadujących z powiatem $i$ (Moran 1950, cyt. za Brzozowska 2011). Sąsiedztwo 
powiatów zdefiniowane zostało w badaniu jako posiadanie wspólnych granic, natomiast granice ustalone zostały na podstawie podkładów kartograficznych dostępnych na http://www.gadm.org/.

Statystyka $I$ Morana może teoretycznie przyjmować wartości spoza zakresu od -1 do 1 . Interpretuje się ją w klasyczny sposób: wartość -1 oznacza maksymalne zróżnicowanie sąsiadujących ze sobą regionów, 0 - brak zależności przestrzennej, oraz 1 - całkowite grupowanie regionów ze względu na poziom zjawiska (Mitchell 2005, Gatrell i Elliott 2009).

W części analiz, która dotyczyła zmian w czasie (pomiędzy latami 1991-1995 oraz 2006-2010) terytorialnego zróżnicowania umieralności ze względu na przyczyny nieznane i niedokładnie określone w Polsce, porównane zostały podstawowe statystyki standaryzowanych odsetków zgonów ze względu na przyczyny NN w powiatach. Jednocześnie w celu pokazania trwałości terytorialnego wzorca zróżnicowania orzecznictwa przyczyn NN w Polsce wyznaczone zostały podstawowe miary statystyczne (średnia, odchylenie standardowe, współczynnik zmienności, wartość minimalna i maksymalna oraz centyle) oraz współczynnik regresji między poziomem zjawiska $\mathrm{w}$ dwóch badanych okresach, a także statystyka $I$ Morana dla zmiany w standaryzowanym odsetku zgonów w powiatach (różnica między stanem w okresie 2006-2010 a stanem w latach 1991-1995).

\section{WYNIKI DLA LAT 2006-2010}

W latach 2006-2010 w Polsce rejestrowano średnio 6,4\% zgonów z przyczyn nieznanych i niedokładnie określonych. W miastach i na wsiach odsetek ten był bardzo zbliżony, a test istotności dla dwóch średnich nie dał podstaw do odrzucenia hipotezy zakładającej taki sam średni poziom zjawiska w tych lokalizacjach ${ }^{8}$. W ujęciu wojewódzkim odsetek ten był bardziej zróżnicowany. Na przykład, w 2010 roku wynosił on od $1 \%$ na Warmii i Mazurach ${ }^{9}$ do prawie $10 \%$ w województwie łódzkim. Na poziomie powiatów różnice te były jeszcze większe: w latach 2006-2010 wartość odsetka zmieniała się od mniej niż 1,5\% w powiecie żywieckim, tczewskim, starogardzkim czy pszczyńskim, do ponad $20 \% \mathrm{w}$ powiecie puławskim, leszczyńskim, ryckim i Lublinie, oraz aż 33\% w powiecie świdnickim (Tablica 1). Współczynnik zmienności dla powiatów wyniósł $58,9 \%$. Wynik ten wskazuje na widoczny, choć umiarkowany poziom zróżnicowania $\mathrm{w}$ orzekaniu przyczyn nieznanych i niedokładnie określonych w polskich regionach.

\footnotetext{
8 Test wykonano dla rozkładu t-studenta dla roku 2010 dla regionów miejskich i wiejskich w poszczególnych województwach.

9 Przypadek Warmii i Mazur jest zresztą wyjątkowy: w ciągu dekady 2000-2010 udział nieznanych i niedokładnie określonych przyczyn wśród wszystkich przyczyn spadł z ponad 14\% do mniej niż $1 \%$.
} 
Umieralność z przyczyn nieznanych i niedokładnie określonych oraz jej trwałe...

Tablica 1. Podstawowe charakterystyki odsetka zgonów z przyczyn nieznanych i niedokładnie określonych (NN) w latach 1991-1995 i 2006-2010

Table 1. Main characteristics of percentage of deaths due to unknown and ill-defined causes, 1991-1995 and 2006-2010

\begin{tabular}{|l|c|c|}
\hline Charakterystyki Characteristics & 1991-1995 & 2006-2010 \\
\hline $\begin{array}{l}\text { Odsetek zgonów z przyczyn NN } \\
\text { Percentage of deaths due to unknown and ill-defined causes }\end{array}$ & 7,7 & 6,4 \\
\hline $\begin{array}{l}\text { Statystyki standaryzowanego odsetka zgonów z przyczyn NN dla powiatów } \\
\text { Statistics of standardized percentage of deaths due to unknown and ill-defined causes in counties }\end{array}$ & 5,1 & 6,5 \\
\hline Średnia* Average* & 3,5 & 3,8 \\
\hline Odchylenie standardowe Standard deviation & 68,4 & 58,9 \\
\hline $\begin{array}{l}\text { Współczynnik zmienności (w \%) } \\
\text { Coefficient of variation (in \%) }\end{array}$ & 0,4 & 1,3 \\
\hline Min & 24,2 & 32,6 \\
\hline Max & 1,17 & 2,16 \\
\hline 5-ty centyl 5th percentile & 11,68 & 13,44 \\
\hline 95-ty centyl 95th percentile & & \\
\hline
\end{tabular}

* Średnia arytmetyczna obliczona dla powiatów różni się od odsetka dla całej Polski, ponieważ nie uwzględniono różnic w liczebnościach osób zmarłych w powiatach.

Źródło: obliczenia własne na podstawie GUS (2013).

* The average calculated for counties (powiats) differs from the percentage for Poland because it was not adjusted according to numbers of deaths in counties.

Source: own elaboration based on GUS (2013).

Na Ryc. 2 widoczne są skupiska powiatów, w których stosunkowo często rejestruje się zgony z przyczyn NN. Dotyczy to, na przykład, w województwie lubelskim, powiatu lubelskiego, świdnickiego, łęczyńskiego i puławskiego, a w województwie łódzkim - poddębickiego, zduńsko-wolskiego i łaskiego. Widać także skupiska powiatów, w których zgony takie rejestruje się stosunkowo rzadko, na przykład w znacznej części województwa kujawsko-pomorskiego oraz północnej części Mazowsza. Trzeba jednak przyznać, iż skupianie się powiatów o podobnych odsetkach zgonów z przyczyn nieznanych i niedokładnie określonych ma umiarkowaną siłę, co potwierdza statystyka $I$ Morana dla terytorialnej autokorelacji pomiędzy powiatami o wartości 0,419 (istotność statystyczna na poziomie $\alpha \leq 0,001$ ). Jest to wynik podobny do wartości uzyskanej przez zespół B. Wojtyniaka (Wojtyniak i in. 2012b), obliczonej na podstawie standaryzowanego wskaźnika umieralności dla przyczyn $R 95-R 99$ dla lat $2008-2011^{10}$.

10 Wartość uzyskana dla mężczyzn wyniosła 0,418, dla kobiet zaś 0,377 (Wojtyniak i in. 2012b). 
Ryc. 2. Standaryzowany odsetek zgonów z przyczyn nieznanych i niedokładnie określonych w latach 2006-2010

Fig. 2. Standardized percentage of deaths due to unknown and ill-defined causes in 2006-2010

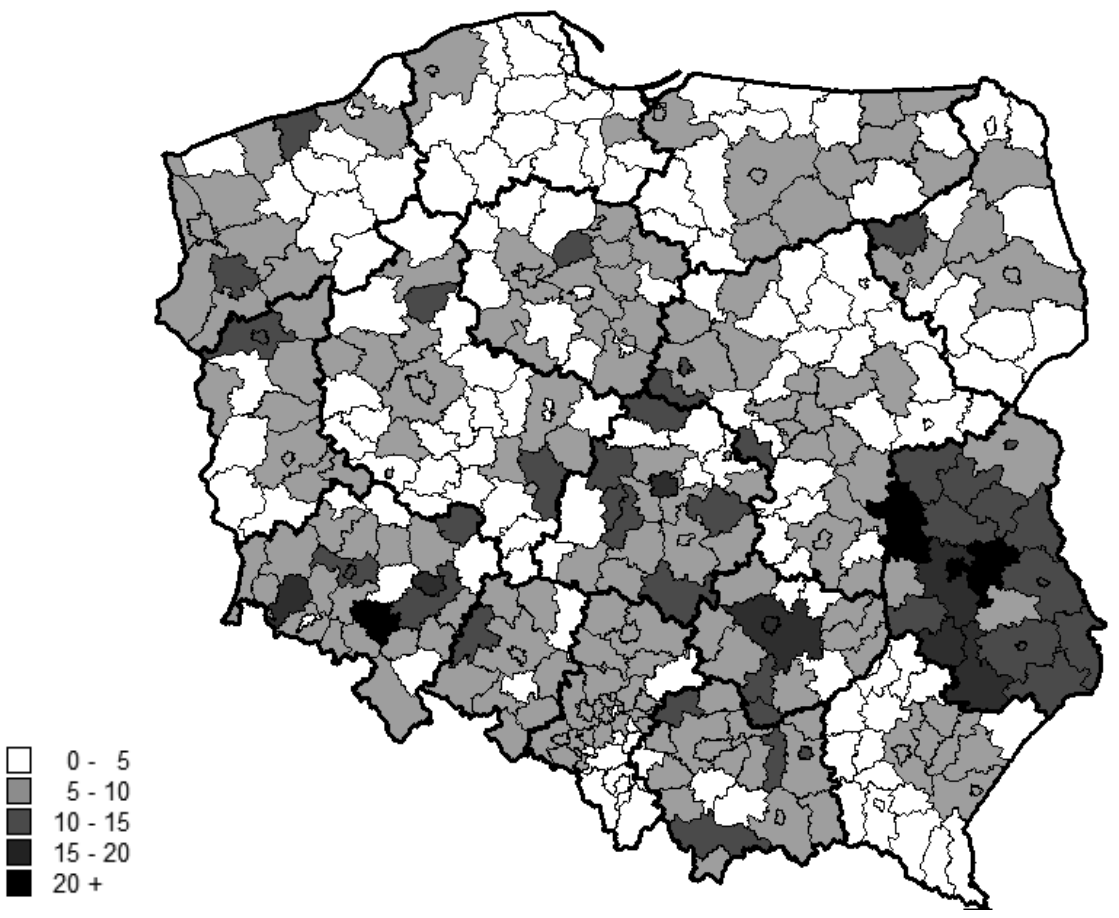

Źródło: opracowanie własne na podstawie GUS (2013).

Source: own elaboration based on GUS (2013)

Dokładniejsza analiza danych wskazuje na istotne różnice w odniesieniu do struktury przyczyn nieznanych i niedokładnie określonych. Na przykład, na Warmii i Mazurach 99\% zgonów z przyczyn niedokładnie określonych zarejestrowano w 2010 roku w odniesieniu do starości (kod R54). W tym samym roku w województwie zachodniopomorskim starość dotyczyła zaledwie 11\% zgonów nieznanych i niedokładnie określonych, a najczęstszą przyczyną z rozdziału „R” była śmierć w ciągu pierwszych 24 godzin od pojawienia się objawów, nie dająca się wytłumaczyć inaczej (R96.1, 43\% zgonów nieznanych i niedokładnie określonych). W województwie dolnośląskim i zachodniopomorskim stosunkowo często rejestrowano zgony z powodu zatrzymania oddechu (R09.2), które stanowiły, odpowiednio, $17 \%$ i $29 \%$ wszystkich zgonów nieznanych i niedokładnie określonych. Ta przyczyna praktycznie nie była orzekana w pozostałych regionach kraju. Nie licząc Warmii i Mazur, odsetek nie w pełni zdiagnozowanych stanów chorobowych i nieznanych przyczyn zgonu (R95-R99) wśród wszystkich przyczyn NN wahał się od 22\% na Pomorzu do $61 \%$ na Ziemi Lubuskiej. Jest wątpliwe, by to sytuacja epidemiologiczna determino- 
Umieralność z przyczyn nieznanych i niedokładnie określonych oraz jej trwałe...

wała tak duże różnice w strukturze przyczyn nieznanych i niedokładnie określonych. Wynik ten wskazuje na występowanie w polskich regionach odmiennych praktyk kodyfikacyjnych.

\section{WYNIKI DLA LAT 1991-1995 W PORÓWNANIU Z LATAMI 2006-2010}

W latach 1991-1995 blisko 8\% zgonów orzeczonych zostało w Polsce jako zgony z przyczyn nieznanych i niedokładnie określonych, co stanowiło nieznacznie wyższy odsetek niż w latach 2006-2010 (Tablica 1). Udział zgonów z przyczyn NN oscylował od 0,4\% (powiat żagański i rawicki) do 24\% (powiat świdnicki), a współczynnik zmienności wyniósł $68,4 \%$, czyli o 10 punktów procentowych więcej niż 15 lat później (Tablica 1). Spadek zróżnicowania terytorialnego w okresie transformacji ustrojowej mierzony za pomocą miary względnej, jaką jest współczynnik zmienności, współwystępował jednak ze wzrostem zróżnicowania w wymiarze absolutnym: odchylenie standardowe wzrosło z $3.5 \%$ do $3.8 \%$.

Ryc. 3. Standaryzowany odsetek zgonów z przyczyn nieznanych i niedokładnie określonych w latach 1991-1995

Fig. 3. Standardized percentage of deaths due to unknown and ill-defined causes in 1991-1995

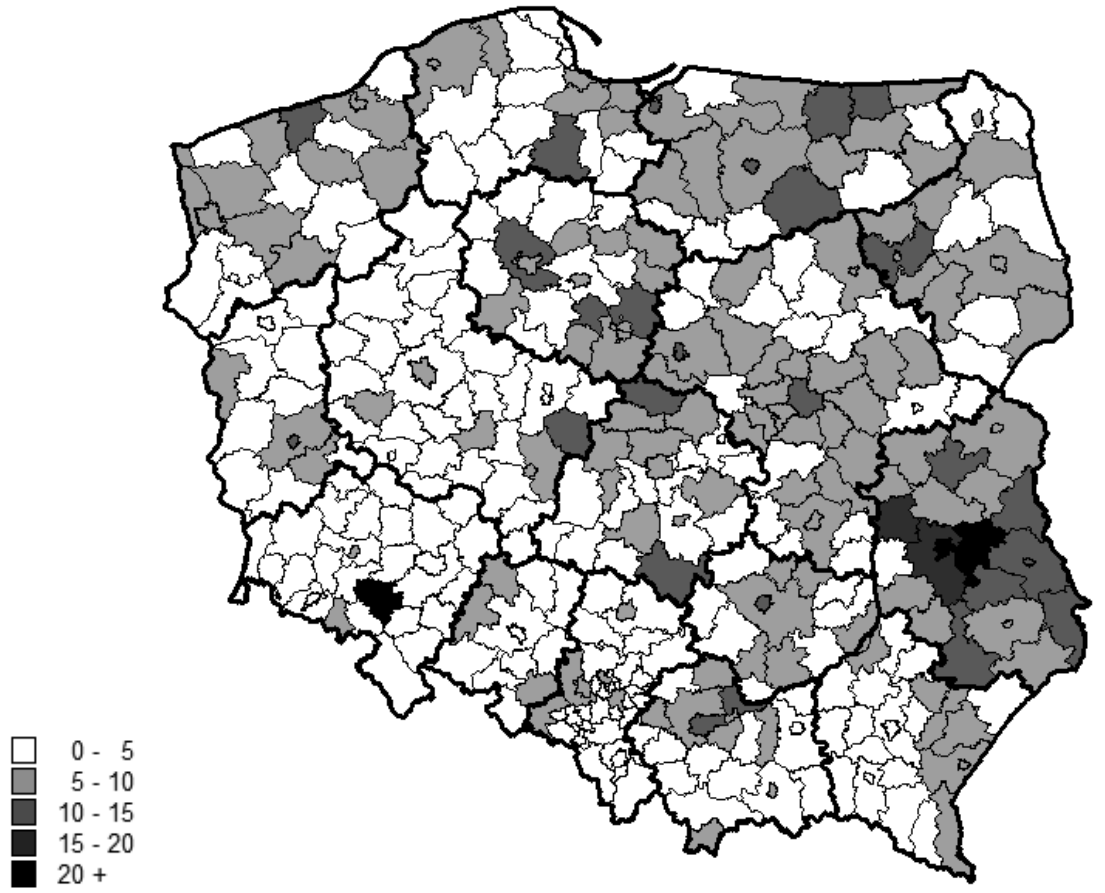

Źródło: opracowanie własne na podstawie GUS (2013).

Source: own elaboration based on GUS (2013). 
Podobnie jak w późniejszym okresie, w latach 1991-1995 widać było skupiska powiatów o stosunkowo częstym (np. w województwie lubelskim) i stosunkowo rzadkim (np. w województwie wielkopolskim) orzekaniu przyczyn nieznanych i niedokładnie określonych (Ryc. 3). Statystyka $I$ Morana dla terytorialnej autokorelacji pomiędzy powiatami wyniosła 0,417 (istotność statystyczna na poziomie $\alpha \leq 0,001$ ), co świadczy o równie umiarkowanej jak w okresie 2006-2010 tendencji do tworzenia się skupisk powiatów o zbliżonych wartościach. Jednocześnie terytorialny wzorzec tych skupisk był bardzo podobny w obu okresach (por. Ryc. 2 i 3), a współczynnik korelacji $r$ Pearsona pomiędzy odsetkami zgonów z przyczyn NN w powiatach między badanymi okresami wyniósł $r=0,60$ i był istotny statystycznie (na poziomie $\alpha \leq 0,05$, Ryc. 4). Wynik ten wskazuje na utrzymywanie się w czasie lokalnych praktyk kodyfikacyjnych w polskich powiatach.

Ryc. 4. Standaryzowany odsetek zgonów z przyczyn nieznanych i niedokładnie określonych w powiatach, 1991-1995 oraz 2006-2010*

Fig. 4. Standardized percentage of deaths due to unknown and ill-defined causes in counties, 1991-1995 and 2006-2010*

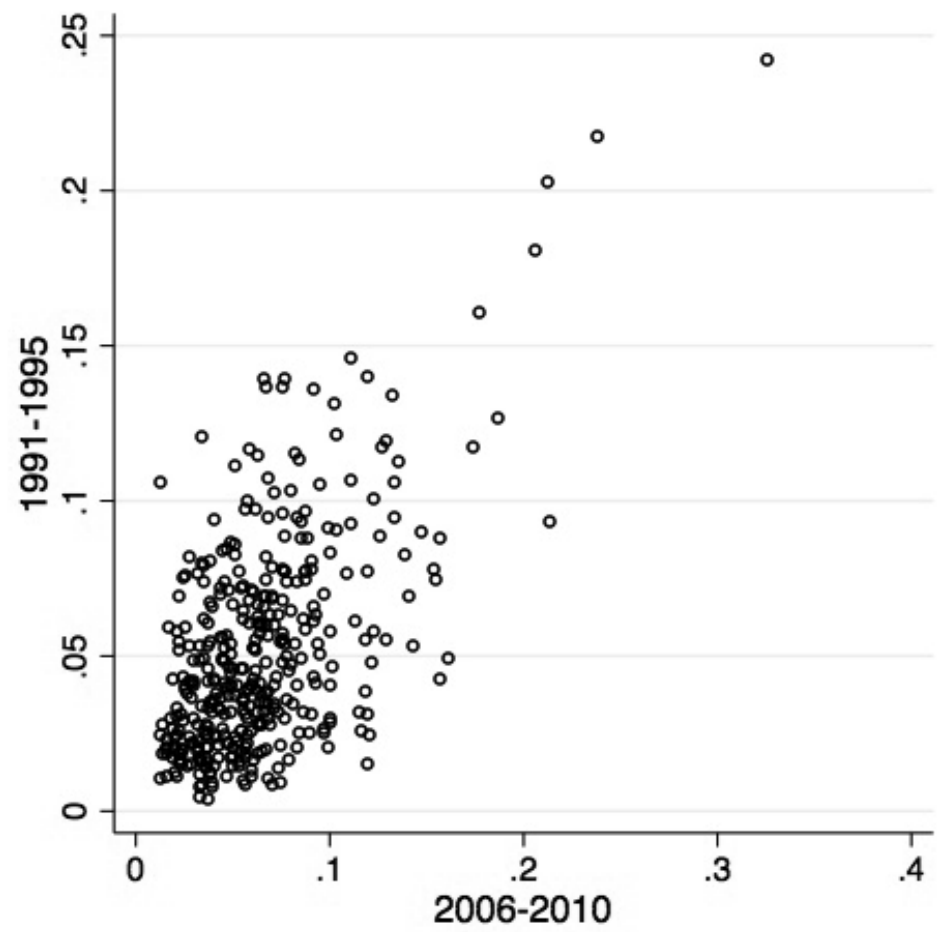

* Wsp. $r$ Pearsona wynosi $0.6, \alpha \leq 0,05$.

Źródło: opracowanie własne na podstawie GUS (2013).

* Pearson's $r=0.6, \alpha \leq 0,05$.

Source: own elaboration based on GUS (2013). 
Umieralność z przyczyn nieznanych i niedokładnie określonych oraz jej trwałe...

Jak już wspomniano, w okresie 2006-2010 rzadziej niż na początku lat 1990tych orzekano zgony z przyczyn nieznanych i niedokładnie określonych. Można zaobserwować pewną zależność, choć niewątpliwie słabą, iż wzrost odsetka zgonów z tychże przyczyn miał miejsce w powiatach, w których skala ich orzecznictwa była początkowo stosunkowo niska (Ryc. 5). Trudno stwierdzić, co mogło być przyczyną tego zjawiska. Wyjątek od tej reguły stanowiły powiaty, w których mimo wysokiego odsetka zgonów z przyczyn NN w latach 1990-tych zarejestrowano stosunkowo duży wzrost w późniejszym okresie, jak na przykład w powiecie świdnickim (województwo dolnośląskie), mieście Lublin, powiecie łęczyńskim, puławskim oraz lubelskim (wszystkie w województwie lubelskim). Najsilniejszy wzrost odsetka wystąpił w powiecie ryckim (województwo lubelskie), lwóweckim i mieście Wrocław (oba w województwie dolnośląskim).

Ryc. 5. Różnica w standaryzowanym odsetku zgonów z przyczyn nieznanych i niedokładnie określonych pomiędzy okresem 2006-2010 i 1991-1995, w punktach procentowych (pp)

Fig. 5. Difference in standardized percentages of deaths due to unknown and ill-defined causes between 2006-2010 and 1991-1995, in percentage points (pp)

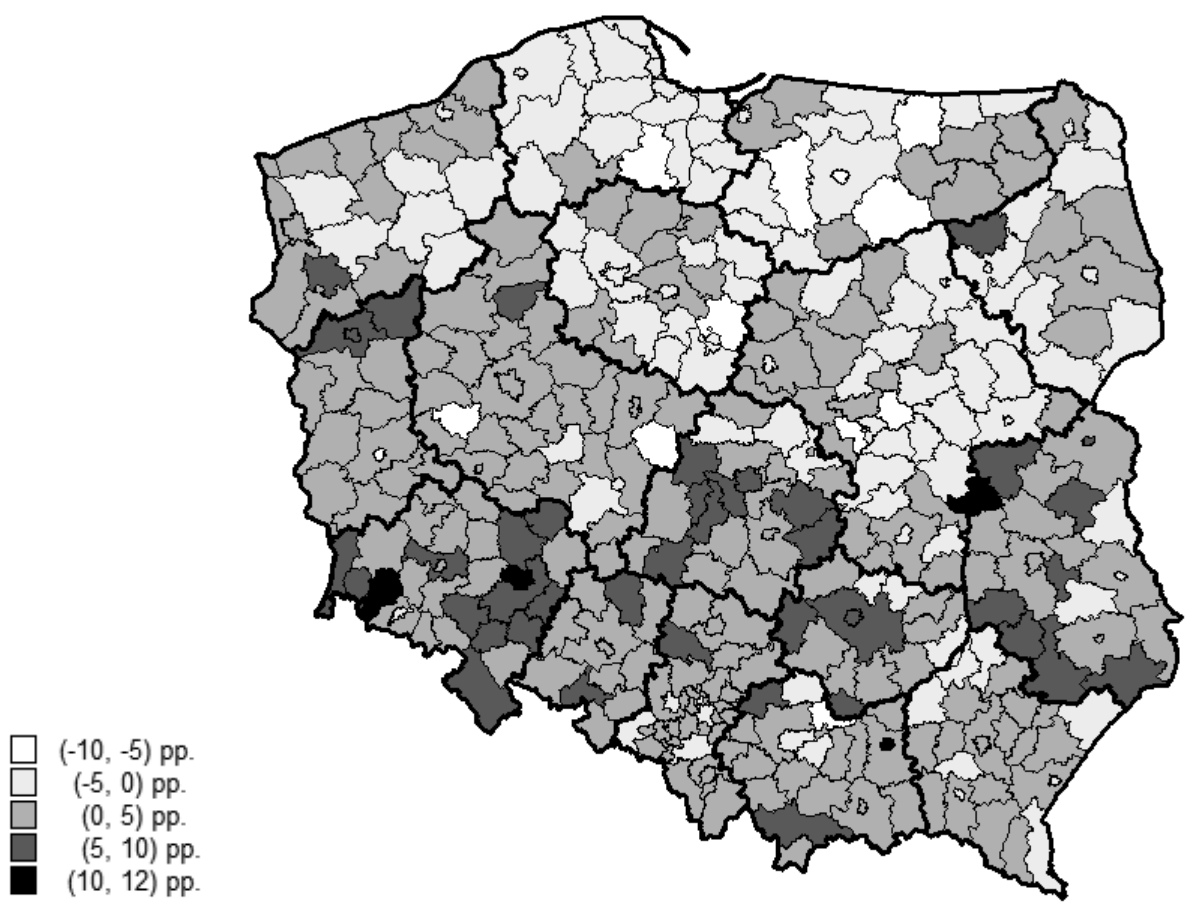

Źródło: opracowanie własne na podstawie GUS (2013).

Source: own elaboration based on GUS (2013). 


\section{PRAKTYKA ORZECZNICTWA O PRZYCZYNACH ZGONU W POLSKIEJ STATYSTYCE PUBLICZNEJ}

W analizowanych okresach, 1991-1995 i 2006-2010, funkcjonowały dwa różne systemy orzecznictwa o przyczynach zgonu. Na początku lat 1990-tych obowiązywała 9-ta rewizja Międzynarodowej Statystycznej Klasyfikacji Chorób, a przyczynę zgonu ustalał lekarz stwierdzający zgon lub przeprowadzający na wniosek prokuratora lub sądu sekcję zwłok. Wprowadzenie 10-tej rewizji Międzynarodowej Statystycznej Klasyfikacji Chorób w 1997 roku oznaczało reorganizację i unowocześnienie systemu orzecznictwa ${ }^{11}$. Zgodnie z Ustawą o statystyce publicznej z 1995 roku (Dz.U. 1995, nr 85, poz. 439, z późniejszymi zmianami) lekarz prowadzący chorego, stwierdzający zgon lub przeprowadzający sekcję zwłok jedynie wpisuje słowną informację dotyczącą bezpośredniej, wtórnej i wyjściowej przyczyny zgonu. Dokument ten jest przekazywany tzw. lekarzowi orzekającemu o wyjściowej przyczynie zgonu, współpracującemu $\mathrm{z}$ regionalnym urzędem statystycznym, który to lekarz ostatecznie ustala przyczynę wyjściową zgonu. W przypadku niepewności lekarz-orzecznik powinien zasięgnąć dodatkowych informacji u lekarza, który stwierdził zgon lub odwołać się do pomocy instytutów medycznych wyznaczonych przez Ustawę. Trzeba podkreślić, iż lekarze orzekający o wyjściowej przyczynie zgonu są osobami o długoletniej praktyce lekarskiej, dużym doświadczeniu, wysoce specjalistycznej wiedzy medycznej i znajomości reguł kodyfikacyjnych sformułowanych przez Światową Organizację Zdrowia. Prawdopodobnie to właśnie ich wiedza i doświadczenie przyczyniły się do spadku rejestracji zgonów z przyczyn nieznanych i niedokładnie określonych po wprowadzeniu 10-tej rewizji Międzynarodowej Statystycznej Klasyfikacji Chorób.

Równocześnie jednak lekarze-orzecznicy (jest ich w Polsce około 35, por. GUS 2007) mogą mieć własne, często odmienne praktyki i zwyczaje kodyfikacyjne, które mogą tłumaczyć regionalne różnice w orzekaniu przyczyn nieznanych i niedokładnie określonych. Dużo zależy od sprawowanego przez nich nadzoru nad lekarzami stwierdzającymi zgon. Ci ostatni mogą pochopnie wypełniać karty zgonu, na przykład wpisując przyczynę nieznaną lub niedokładnie określoną, taką jak śmierć nieoczekiwana (R98), lub w ogóle nie wpisywać bezpośredniej, wtórnej ani wyjściowej przyczyny. Może to wynikać z niechęci lekarzy do wypełniania dokumentacji medycznej, obowiązku będącego - zdaniem lekarzy - formalnością niepotrzebną, nieistotną dla statystyki publicznej (Susło 2011).

Częsta rejestracja zgonów z przyczyn NN może też wynikać z niepewności lekarzy stwierdzających zgon co do procesów lub okoliczności zdarzeń prowadzących do śmierci, zwłaszcza przy braku informacji o historii choroby czy nieznajomości pacjenta. W takich przypadkach lekarze wolą nie wypełniać karty zgonu w zakresie przyczyn niż wpisać diagnozę nieprawidłową lub taką, co do której nie mają pew-

\footnotetext{
11 Szerzej o tym w m.in. Fihel (2011).
} 
Umieralność z przyczyn nieznanych i niedokładnie określonych oraz jej trwałe...

ności. Wyniki przedstawionego badania sugerują, że są w Polsce regiony, w których lekarze stwierdzający zgon są bardziej - niż w innych regionach - skłonni do niedokładnego wypełniania kart zgonu, a lekarze-orzecznicy nie wyjaśniają tych przypadków. Niekiedy ma miejsce sytuacja zupełnie odmienna, kiedy lekarze stwierdzający zgon sami wpisują w kartę zgonu kod wyjściowej przyczyny zgonu, przekraczając tym samym swoje uprawnienia, ponieważ zakodowanie i ostateczne zatwierdzenie wyjściowej przyczyny zgonu jest zadaniem lekarza-orzecznika, osoby bardziej kompetentnej w dziedzinie reguł kodyfikacyjnych. O praktyce tej, niezgodnej z rozporządzeniem Ministra Zdrowia z dnia 7 grudnia 2001 roku, wspominają B. Wojtyniak i współpracownicy (2012a).

Niewątpliwie bardzo istotne znaczenie dla orzekania nieznanych i niedokładnie określonych przyczyn ma miejsce, w którym nastąpił zgon. Jeśli jest to szpital lub inny zakład opieki zdrowotnej, gdzie istnieje dokumentacja medyczna i wykonane zostały badania służące diagnostyce choroby, to wypełnienie karty zgonu w zakresie przyczyn nie powinno nastręczać większych trudności. W innej sytuacji jest lekarz, najczęściej pogotowia, wezwany do osoby, która zmarła w domu lub innym miejscu, a który nie zna osoby i nie ma dostępu do jej historii choroby, a przez to nie ma podstaw do stwierdzenia rozpoznania przyczyny zgonu, w szczególności przyczyny wtórnej i wyjściowej ${ }^{12}$. Jeśli nie występują podejrzenia zaistnienia przyczyny kryminalnej zgonu, lekarz nie ma też podstaw do wniosku o badanie post-mortem. $\mathrm{O}$ różnicy w praktyce orzecznictwa realizowanej w zakładach opieki zdrowotnej i poza nimi świadczy to, że zgony w domach są dużo częściej rejestrowane jako te z przyczyn NN. Na przykład, w 2011 roku w domu zmarło 37\% osób, w szpitalu lub innym zakładzie opieki zdrowotnej $-58 \%$, a w innym miejscu $-6 \%$. Tymczasem wśród osób zmarłych z przyczyn NN aż 72\% zmarło w domu, jedynie 14\% - w szpitalu lub innym zakładzie opieki zdrowotnej, a pozostałe $14 \%$ - w innym miejscu ${ }^{13}$. Stopniowa zmiana polegająca na rosnącym udziale szpitali i innych miejsc opieki zdrowotnej jako miejsc zgonu ${ }^{14}$ sprzyjać będzie zmniejszeniu skali orzecznictwa umieralności z przyczyn należących do rozdziału „R”.

Reasumując, o terytorialnym zróżnicowaniu umieralności z przyczyn nieznanych i niedokładnie określonych decyduje po pierwsze, staranność lekarzy stwierdzających zgon przy wypełnianiu dokumentacji medycznej oraz po drugie, dociekliwość lekarzy-orzeczników przy wyjaśnianiu okoliczności zgonu w przypadkach wątpliwych lub nieopisanych przez lekarzy stwierdzających zgon. Potwierdzają to badania, między innymi W. Jędrychowskiego i współautorów (2001), którzy na przykładzie Krakowa pokazali pomijanie przez lekarzy stwierdzających zgon ważnych informa-

12 Być może pełniejsze informacje o przyczynie zgonów można by uzyskać poprzez kontakt z lekarzem rodzinnym, szczególnie w przypadku osób starszych, które zmarły w domu (przyp. aut.).

13 Niestety, nie dysponujemy analogicznymi danymi dla każdego z powiatów lub województw, co pozwoliłoby na bardziej szczegółową analizę okoliczności orzekania przyczyn NN.

14 Na przykład, w 1990 roku 45\% zgonów miało miejsce w domu i 48\% w szpitalu lub innym zakładzie opieki zdrowotnej (GUS 2012). 
cji o przyczynach bezpośrednich i wtórnych. Badanie zrealizowane przez Główny Urząd Statystyczny w 2005 roku w wybranych województwach Polski (GUS 2007) polegało na ponownym ustaleniu wyjściowych przyczyn w wybranych kartach zgonu. W co piątym przypadku wyjściowa przyczyna zgonu była zakodowana nieprawidłowo, a w wyniku ponownej analizy dokumentacji znacząco zmniejszyła się liczba zgonów z powodu starości (o 22\%) oraz zgonów w ciągu pierwszych 24 godzin od pojawienia się objawów nie dających się wythumaczyć inaczej (o 78\%).

\section{PODSUMOWANIE I DYSKUSJA}

Skala rejestracji przyczyn nieznanych i niedokładnie określonych, a także wybranych kategorii przyczyn NN jest w Polsce silnie zróżnicowana pod względem terytorialnym. Zjawisko to jest stosunkowo trwałe i ma miejsce co najmniej od początku transformacji ustrojowej. $Z$ jednej strony występuje widoczne, choć statystycznie umiarkowane zróżnicowanie województw oraz powiatów pod względem częstości rejestracji przyczyn nieznanych i niedokładnie określonych; z drugiej strony sąsiadujące ze sobą powiaty charakteryzują się podobną skalą tego zjawiska. Tego stanu rzeczy nie zmieniło wprowadzenie 10-tej rewizji i reorganizacja systemu orzekania przyczyn zgonów w 1997 roku. Wręcz przeciwnie, absolutna wartość zróżnicowania skali orzekania przyczyn $\mathrm{NN}$ w polskich powiatach wzrosła w badanym okresie, pomimo oddania zadania zatwierdzania przyczyn zgonów w ręce wysoce wykwalifikowanych w tym zakresie lekarzy. Wyniki te świadczą o odmiennych praktykach kodyfikacyjnych stosowanych przez lekarzy pracujących w poszczególnych regionach kraju i stwierdzających zgon oraz orzekających o przyczynach zgonu. To właśnie od ich staranności i dociekliwości zależy jakość danych dotyczących przyczyn zgonu, między innymi rzadkie (lub częste) orzekanie o przyczynach nieznanych i niedokładnie określonych.

Problemy związane $\mathrm{z}$ wypełnianiem kart zgonu w zakresie przyczyn nie dotyczą wyłącznie dla Polski, lecz występują one także w krajach o relatywnie dobrej jakości danych (por. np. Bijak 2003, Meslé 2006, Anderson 2011). Istnieją jednak rozwiązania, które poprawiłyby jakość polskich danych dotyczących umieralności. Do zmniejszenia odsetka zgonów z przyczyn nieznanych i niedokładnie określonych przyczyniłoby się położenie większego nacisku w trakcie studiów medycznych na reguły wypełniania dokumentacji oraz definiowania bezpośredniej, wtórnej i wyjściowej przyczyny zgonu. Wypełnianie kart zgonów powinno być postrzegane przez personel medyczny jako czynność ważna dla pozyskania dobrej jakości danych pozwalających na ocenę sytuacji epidemiologicznej oraz dla prowadzenia odpowiedniej polityki zdrowotnej.

Dyskusyjna jest kwestia zwiększenia liczby badań pośmiertnych. W Polsce badania post mortem wykonuje się stosunkowo rzadko, w przypadku około 7\% zgonów, i odsetek ten pozostaje od dekady na stałym poziomie. W krajach wysoko rozwinię- 
Umieralność z przyczyn nieznanych i niedokładnie określonych oraz jej trwałe...

tych skala takich badań jest bardzo zróżnicowana, a od końca lat 80 . obserwuje się tendencję spadkową wykonywania sekcji zwłok. Na przykład, odsetek sekcji zmalał we Francji z 15,4 (w roku 1988) do 3,7\% (1997) zgonów, w Irlandii z 30,4 (1990) do 18,4\% (1999), w Stanach Zjednoczonych z 26,7 (1967) do 12,4\% (1993), w Szwecji z 81 (1984) do 34\% (1993), a w Wielkiej Brytanii z 42,7 (1979) do 15,3\% (2001) (Burton i Underwood 2007). W Polsce zwiększenie liczby sekcji zwłok łączyłoby się z dużym kosztem i nie przeciwdziałałoby pierwotnemu powodowi częstej rejestracji zgonów NN, jakim jest specyficzny sposób pracy lekarzy zaangażowanych w orzekanie przyczyn zgonu.

Poważnym problemem nie jest jedynie relatywnie duża skala orzecznictwa zgonów z przyczyn NN, ale również - a może i przede wszystkim - jej utrzymujące się i rosnące zróżnicowanie terytorialne. Zróżnicowanie to świadczy bowiem o utrzymywaniu się lokalnych praktyk odnośnie wypełniania kart zgonu i kodowania przyczyn zgonu, co utrudnia porównania międzyregionalne i ogólnopolskie. Jak wspomniano powyżej, w Polsce jest około 35 lekarzy-orzeczników, a średnia liczba kart zgonu przypadająca na jednego z nich wynosi około 10 tys. rocznie. Oznacza to, że jeden lekarz-orzecznik analizuje około 50 kart zgonu dziennie, co może stanowić zbyt duże obciążenie dla osoby chcącej wyjaśniać okoliczności wszystkich zgonów, o których informacje nie są wystarczające. Zwiększenie liczby lekarzy orzeczników na pewno spowodowałoby wydłużenie czasu poświęconego na orzeczenie przyczyny w przypadku pojedynczego zgonu. Ten dodatkowy czas mógłby zostać poświęcony kontaktowi z lekarzem stwierdzającym zgon lub lekarzem prowadzącym w celu poznania historii choroby i okoliczności zgonu.

Istnieje jednak obawa, że wzrost liczby lekarzy-orzeczników mógłby doprowadzić do jeszcze większego zróżnicowania praktyk kodyfikacyjnych w poszczególnych regionach kraju. Główny Urząd Statystyczny i Ministerstwo Zdrowia - instytucje odpowiedzialne za zbieranie danych o zgonach i ich przyczynach - organizują co roku wspólne szkolenia dla lekarzy-orzeczników; być może jednak instytucje te powinny położyć większy nacisk na zacieśnienie współpracy między lekarzami-orzecznikami pochodzącymi z różnych regionów kraju, tak by współpraca ta miała miejsce w codziennej pracy. W celu upowszechnienia wiedzy o prawidłowym podawaniu informacji o przyczynach zgonu, zapewne też z myślą o lekarzach orzekających o zgonie, na stronie internetowej GUS zamieszczono podręcznik poświadczania przyczyn zgonów w Europie oraz przykładowe, oryginalne zapisy na kartach zgonu. Równocześnie zaapelowano o „rzetelne i skrupulatne wypełnianie kart zgonów [które] powinno być zatem traktowane jako nieodzowna praktyka zwiększająca wartość merytoryczną danych o przyczynach zgonów" (GUS 2014: 2). Trudno jednak powiedzieć, czy taka pośrednia forma komunikacji z lekarzami uczestniczącymi w procesie orzekania przyczyn zgonu będzie wystarczająco efektywna.

Problemy związane z wypełnianiem kart zgonu można by w pewnym stopniu rozwiązać za pomocą elektronicznej karty pacjenta, o której wdrożeniu przez Ministerstwo Zdrowia w systemie opieki zdrowotnej w Polsce mówi się już od jakiegoś 
czasu. Wprowadzenie takich kart stworzyłoby możliwość względnie łatwego dostępu lekarzy do informacji dotyczących historii choroby i wykonywanych zabiegów, a przez to podniosłoby kompletność i jakość w zakresie informacji o przyczynach zgonu. Rozwiązanie to byłoby szczególnie praktyczne w przypadku zgonów mających miejsce $\mathrm{w}$ domu, ponieważ lekarz-orzecznik miałby wgląd zarówno w dane dotyczące historii choroby i leczenia, jak i w informacje kontaktowe do lekarzy, którzy jako ostatni zajmowali się chorym przed jego zgonem. To właśnie w stosunku do zgonów mających miejsce w domu nadzwyczaj często orzeka się przyczyny NN, dlatego bardziej wnikliwa analiza dokumentacji osób zmarłych w domu byłaby najlepszym sposobem na zmniejszenie liczby zgonów z przyczyn nieznanych i niedokładnie określonych tak na poziomie lokalnym, jak i ogólnopolskim.

\section{LITERATURA}

Anderson R., 2011, Coding and Classifying Causes of Death: Trends and International Differences, [w:] R. Rogers, E. Crimmins (red.), International Handbook of Adult Mortality (s. 467-489, t.2), Springer, Dordrecht.

Bijak J., 2003, Międzynarodowa porównywalność danych o zgonach wedtug przyczyn $w$ badaniu regionalnych różnic umieralności na przykładzie Czech. Holandii i Polski w latach 1994-1996, „Studia Demograficzne”, nr 2/144, 3-53.

Brzozowska Z., 2011, Przestrzenne zróżnicowanie urodzeń pozamatżeńskich $w$ Polsce $w$ latach 2002-2010, „Studia Demograficzne”, nr 2/160, 59-83.

Burton J., Underwood J., 2007, Clinical, educational, and epidemiological value of autopsy, „Lancet”, 369 , s. 1471-1480.

Eurostat, 2013, Statistics - Public Health, baza danych dostępna na stronie: http://epp.eurostat.ec.europa eu/

Fihel A., 2011, Umieralność wedlug pojedynczych przyczyn zgonu: rekonstrukcja danych dla Polski 1970-2009, „Studia Demograficzne”, nr 2/160, 3-33.

Gatrell A. C., Elliott S. J., 2009, Geographies of health: An introduction, John Wiley \& Sons.

Gavrilova N., Semyonova V., Dubrovina E., Evdokushkina G., Ivanova A., Gavrilov L., 2008, Russian Mortality Crisis and the Quality of Vital Statistics, "Population Research and Policy Review", 27, $5,551-574$.

GUS, 2007, Final report within Project No 14, Improvement of statistics of causes of death, Transition Facility 2004 - 19100.2005.001-2005.536, raport niepublikowany, Warszawa.

GUS, 2012, Rocznik Demograficzny 2012, Warszawa.

GUS, 2013, Baza Demografia, baza danych dostępna na stronie: http://demografia.stat.gov.pl/ bazademografia/Tables.aspx

GUS, 2014, Na co umarl pacjent - czyli, co jest wpisywane na kartach zgonów?, GUS, Warszawa, dostępne na: http://stat.gov.pl/obszary-tematyczne/ludnosc/statystyka-przyczyn-zgonow/_(dostęp z dnia 20.05.2014).

Human Mortality Database, 2013, University of California, Berkeley (USA), and Max Planck Institute for Demographic Research (Germany). Dostępne na stronie: http://www.mortality.org (dostęp z dnia 05.07.2013).

Jędrychowski W., Mróz E., Wiernikowski A., Flak E., 2001, Trafność wyboru przez lekarza wyjściowej przyczyny zgonu i kodowania danych z kart zgonów, ,Przegląd Epidemiologiczny”, 55, 3, 313-322.

Kupść W., Piotrowski W., Kurjata B., Salaterski W., Broda G., Drygas W., 2008, Atlas umieralności spowodowanej chorobami uktadu krążenia w Polsce w latach 1997-2005, Instytut Kardiologii w Warszawie, Warszawa. 
Umieralność z przyczyn nieznanych i niedokładnie określonych oraz jej trwałe...

Mathers C., Ma Fat D., Inoue M., Rao C., Lopez A., 2005, Counting the dead and what they died from: An assessment of the global status of cause of death data, „Bulletin of the World Health Organization", 83, 171-177.

Meslé F., 2002, The registration of causes of death: Problems of comparability, [w:] Wunsch G., Mouchart M., Duchene J. (eds.), The Life Table. Modelling Survival and Death (s. 171-190), European Studies of Population, EAPS, Kluwer Academic Publishers, Dordrecht.

Meslé F., 2006, Medical Causes of Death, [w:] G. Caselli, J. Vallin, G. Wunch (red.), Demography. Analysis and Synthesis. A Treatise in Population Studies (s. 45-70, vol.2), Elsevier, Amsterdam, Boston.

Mitchell A., 2005, The ESRI guide to GIS analysis, tom 2: Spatial Measurements and Statistics, ESRI, Redlands.

Moran P.A.P., 1950, Notes on Continuous Stochastic Phenomena, „Biometrika”, nr 37, 17-23.

Nolte E., Shkolnikov V., McKee M., 2000, Changing mortality patterns in East and West Germany and Poland II: short term trends during transition and in the 1990s, ,Journal of Epidemiology and Community Health", 54, 899-906.

Pechholdová M., Fihel A., 2013, Understanding recent mortality reversal in Central Europe: case of Czech Republic and Poland, referat prezentowany na 27 Międzynarodowym Kongresie Ludnościowym w Busan, Korea Południowa, 26-31.08.2013.

Susło R., 2011, Dokumentacja medyczna - uciążliwość czy ostatnia deska ratunku?, materiał z konferencji „Prawo a Medycyna” we Wrocławiu, dostępne też na stronie: http://www.prawoamedycyna. interpolska.pl/assets/Uploads/Prezentacje/Robert-Suslo-Dokumentacja-medyczna.pdf (data dostępu 20.07.2012).

WHO, 2013, WHO methods and data sources for global causes of death, 2000-2011, WHO, Genewa.

Wojtyniak B., Jankowski K., Zdrojewski T., Opolski G., 2012a, Regional differences in determining cardiovascular diseases as the cause of death in Poland: time for change, „Kardiologia Polska”, 70, 7, 695-701.

Wojtyniak B., Rabczenko D., Pokarowski P., Poznańska A., Stokwiszewski J., 2012b, Atlas umieralności ludności Polski w latach 1999-2001 i 2008-2010, wydanie internetowe; http://www.atlas.pzh.gov. pl (data dostępu 9.03.2013).

Zatoński W., Tyczyński J. (red.), 1999, Nowotwory złośliwe w Polsce w 1996 roku, Centrum Onkologii, Warszawa.

\title{
MORTALITY DUE TO UNKNOWN AND ILL- DEFINED CAUSES AND ITS PERSISTENT TERRITORIAL VARIATION IN POLAND
}

\begin{abstract}
An effective health policy can be only conducted on the basis of complete and up-to-date statistical data referring to, among others, causes of deaths. The share of deaths due to unknown and ill-defined causes constitutes one of quality indicators of data on mortality. As compared to other European countries, in Poland this share is relatively high, especially in some regions of the country. Presented analysis is devoted to spatial differences of mortality due to unknown and ill-defined causes in 1991-1995 and 2006-2010. Despite the introduction of the $10^{\text {th }}$ revision of the
\end{abstract}


International Statistical Classification of Diseases and Related Health Problems, as well as despite the modernization of data collecting system in 1997, spatial differences remained at a constant and moderate level, which probably results from the prevalence of local coding practices. We propose possible solutions that could contribute to decrease in share of death due to unknown and ill-defined causes in Poland, among them standardization of local coding procedures concerning causes of death.

Keywords: unknown and ill-defined causes of death, mortality by causes of death, territorial / spatial diversity, Poland 